\title{
APLIKASI VARIASI SUKROSA DAN PERBANDINGAN GELATIN-KARAGENAN PADA PERMEN JELI KOPI ROBUSTA (Coffea canephora P.)
}

Application of Sucrose Variation and Ratio of Carrageenan-Gelatin in Robusta Coffee (Coffea canephora P.) Jelly Candy

\author{
Septy Handayani ${ }^{1) *}$, Triana Lindriati ${ }^{2)}$, Fuji Kurniawati ${ }^{2)}$, Puspita Sari ${ }^{2)}$ \\ ${ }^{1)}$ Program Studi Gizi, Fakultas Kesehatan Masyarakat, Universitas Jember \\ ${ }^{2)}$ Jurusan Teknologi Hasil Pertanian, Fakultas Teknologi Pertanian, Universitas Jember \\ Jalan Kalimantan I No. 37 Jember, 68121, Jawa Timur, Indonesia \\ *Korespondensi Penulis: septyhandayani@unej.ac.id
}

\begin{abstract}
Robusta coffee is widely cultivated in Indonesia, and it is often processed into ground coffee. In this study, coffee jelly candy was made for product diversification of coffee. In this case, gel forming agents and sugar are needed to build jelly candy texture, aroma, and taste. The aim of this research was to study the characteristics of coffee jelly candy as affected by sucrose concentration and ratio of carrageenan to gelatin. A completely randomized design using two factors (sucrose concentration of $40 \%$ and $60 \%$; and gelatin to carrageenan ratio of 25:75, 50:50, and 75:25 w/w) was employed. The result showed that sucrose concentrations and gelatin to carrageenan ratio significantly ( $\alpha>5 \%)$ affected texture, color, moisture content, ash content, and organoleptic parameters (preference towards color, texture, taste, and overall). However, sucrose concentration and ratio of gelatin to carrageenan not significantly $(\alpha<0,05 \%)$ affect antioxidant activity and polyphenol concentration. The effectiveness test showed that coffee jelly candy with $40 \%$ sucrose concentration and ratio of gelatin:carrageenan 50:50 had the highest score with L (lightness) value of 46.79, hardness of $54.53 \mathrm{~g} / \mathrm{mm}$, moisture content of $19.26 \%$, ash content of $1.36 \%$, antioxidant activity of $26.63 \%$, total polyphenol of $0.46 \mathrm{mg} \mathrm{GAE} / \mathrm{mL}$, preference towards color of 5.60 (rather like), preferences towards aroma of 5.83 (rather like), preferences towards taste of 5.10 (rather like), preferences towards texture of 5.13 (rather like), and overall preference of 5.57 (rather like).
\end{abstract}

Keywords: carrageenan, gelatin, jelly candy, organoleptic, robusta, sucrose

\section{PENDAHULUAN}

Kopi merupakan salah satu jenis minuman dengan cita rasa yang khas dan memberikan pengaruh fisiologis kesegaran sehingga kopi banyak diminati oleh masyarakat di seluruh dunia. Tanaman kopi yang dikembangkan di Indonesia adalah kopi arabika dan kopi robusta. Jenis kopi yang dominan diusahakan di Indonesia yaitu kopi robusta (Coffea canephora P.), meliputi $90 \%$ dari luas lahan kopi secara keseluruhan. Hal ini terlihat pada perkembangan produksi kopi, pada tahun 2013 tercatat 675.881 ton dan terus meningkat hingga tahun 2019 menjadi sebesar 729.074 ton (Direktorat Jenderal Perkebunan, 2019). Produk diversifikasi dari olahan kopi sudah banyak ditemui di
Indonesia, salah satunya adalah permen, namun belum dijumpai olahan permen jeli dari kopi. Permen jeli dengan penambahan kopi dapat meningkatkan sifat fungsional permen jeli karena adanya kandungan antioksidan dalam kopi. Antioksidan dalam kopi yaitu methylpridinium yang dibentuk oleh degradasi trigonelina selama proses pemanasan (Stadler et al., 2002).

Permen jeli adalah kembang gula bertekstur lunak yang diproses dengan penambahan komponen hidrokoloid seperti agar, gum, pektin, pati, karagenan, dan gelatin yang digunakan untuk modifikasi tekstur sehingga menghasilkan produk yang kenyal. Permen jeli diproduksi dengan memanaskan gelling agents dan gula (sukrosa) pada suhu tinggi $\left(>100^{\circ} \mathrm{C}\right)$ 
(Riedel et al., 2015). Sukrosa pada permen jeli digunakan sebagai bahan utama karena memberikan aroma, rasa, dan tekstur yang khas. Sukrosa berpengaruh terhadap pembuatan permen jeli yang berfungsi untuk meningkatkan intensitas rasa manis, membentuk tekstur yang liat, dan menurunkan kekerasan. Berdasarkan penelitian Marsigit et al. (2018), penambahan konsentrasi sukrosa sebanyak $60 \%$ dan karagenan sebanyak $13 \%$ menunjukkan kualitas soft candy jeruk kalamansi yang paling baik. Pembuatan permen jeli melibatkan bahan pembentuk gel yang berfungsi untuk mengontrol kadar air, menstabilkan, dan membentuk tekstur sesuai dengan keinginan. Bahan pembentuk gel yang biasa digunakan adalah karagenan dan gelatin.

Karagenan adalah polisakarida yang diesktraksi dari beberapa spesies rumput laut atau alga merah (Campo et al., 2009). Konsentrasi karagenan berpengaruh nyata terhadap tekstur permen jeli nanas (Wijana et al., 2014). Kelemahan penambahan karagenan yaitu gel yang dibentuk memiliki tekstur yang rapuh dan kurang elastis. Oleh karena itu perlu ditambahkan bahan pembentuk gel lainnya seperti gelatin. Gelatin merupakan produk alami yang diperoleh melalui hidrolisis parsial kolagen dari kulit dan tulang hewan (Duconseille et al., 2015). Gelatin ini memiliki sifat kekenyalan yang khas karena bersifat gelling agent sehingga banyak digunakan untuk pembuatan permen jeli. Menurut Basuki et al. (2014), gelatin dalam pembuatan permen jeli berfungsi sebagai pembentuk gel. Namun, penambahan gelatin yang terlalu banyak menyebabkan nilai hardness permen jeli semakin meningkat sehingga kurang disukai oleh konsumen (Prihardhani \& Yunianta, 2016). Oleh karena itu, penelitian tentang permen jeli kopi dengan variasi konsentrasi sukrosa serta perbandingan karagenan dan gelatin perlu dilakukan untuk mengetahui pengaruh terhadap sifat fisik, kimia, dan organoleptik.
Penelitian ini bertujuan untuk mengetahui konsentrasi sukrosa, gelatin, dan karagenan yang tepat pada pembuatan permen jeli kopi robusta. Selain itu, diharapkan konsentrasi sukrosa, gelatin, dan karagenan dapat memperbaiki penampilan secara fisik dan rasa dari permen jeli.

\section{METODE PENELITIAN}

\section{Alat dan Bahan}

Alat-alat yang digunakan untuk pembuatan permen jeli kopi robusta adalah pisau, loyang, mangkuk, panci, sendok, gelas ukur, timbangan digital (Excell Elw Plus), hot plate stirrer (Faithful SH-3), stirrer bar, kulkas, dan cetakan jeli. Alatalat untuk analisis adalah rheotex (type SD70011), colour reader (Konika Minolta tipe CR 400 Jepang), dan alat-alat gelas.

Bahan yang digunakan untuk pembuatan permen jeli adalah bubuk kopi robusta, air, sukrosa, gelatin, karagenan, sirup glukosa, dan asam sitrat. Bahan untuk analisis adalah methanol p.a, aquades, reagen DPPH (2.2-diphenyl-1-picrydrazyl), follin ciocalteu, $\mathrm{Na}_{2} \mathrm{CO}_{3} 70 \%$, etanol $95 \%$, asam galat, alumunium foil, dan kertas saring.

\section{Tahapan Penelitian}

Pembuatan Ekstrak/Seduhan Kopi Robusta Kopi bubuk sebanyak $30 \mathrm{~g}$ dicampurkan dengan air mendidih sebanyak $150 \mathrm{~mL}$ [perbandingan bubuk kopi:air = 1:5 (b/b)]. Selanjutnya direndam atau didiamkan selama \pm 5 menit sampai terjadi pengendapan. Setelah itu air seduhan yang terpisah dari endapan diambil $50 \mathrm{~mL}$ untuk dicampurkan ke adonan permen jeli.

\section{Pembuatan Permen Jeli Kopi}

Sukrosa $(40 \%$ dan $60 \%)(\mathrm{b} / \mathrm{b})$ dan perbandingan gelatin-karagenan (25\%:75\%, 50\%:50\%, 75\%:25\%) (b/b) dilarutkan dengan air panas (suhu $\pm 80^{\circ} \mathrm{C}$ ) kemudian kedua larutan diaduk selama 5- 
10 menit hingga terbentuk massa jeli. Sirup glukosa dan asam sitrat ditambahkan pada suhu $\pm 75^{\circ} \mathrm{C}$. Selanjutnya seduhan kopi ditambahkan ke dalam campuran, diaduk hingga mengental selama 5 menit. Massa yang terbentuk dituangkan ke dalam cetakan dan dibiarkan 20 menit pada suhu ruangan. Kemudian dimasukkan ke dalam lemari pendingin pada suhu $5^{\circ} \mathrm{C}$ selama 12 jam. Permen jeli yang sudah terbentuk dikeluarkan dari cetakan lalu siap dianalisis.

\section{Rancangan Percobaan}

Penelitian ini menggunakan rancangan acak lengkap (RAL) dua faktor dengan tiga kali ulangan. Faktor A adalah sukrosa dengan variasi konsentrasi $40 \%$ dan $60 \%$ (b/b). Faktor B adalah perbandingan gelatin dan karagenan yaitu 25\%:75\%, 50\%:50\%, dan 75\%:25\% (b/b). Analisis statistik dengan sidik ragam (ANOVA), apabila terdapat perbedaan dilanjutkan dengan uji DNMRT (Duncan's New Multiple Range Test) pada taraf uji $\alpha$ $(0,05)$. Data organoleptik dianalisis menggunakan chi-square pada taraf uji $\alpha$ $(0,05)$. Data diolah dengan Microsoft Excel dan SPSS 24 (statistical product and service solution). Hasil yang didapatkan kemudian disajikan dalam bentuk grafik.

\section{Metode Analisis}

Produk permen jeli kopi diuji sifat fisik (tekstur dan warna), kadar air, kadar abu, antioksidan, polifenol, dan organoleptik. Uji fisik dilakukan dengan mengukur tekstur (hardness) menggunakan rheotex dan pengukuran warna (lightness) menggunakan colour reader. Uji kadar air dan kadar abu dengan metode oven (AOAC, 2005). Uji antioksidan dengan metode DPPH (Liu et al., 2009) dan uji polifenol dengan metode Folin-Ciocalteau (Roy et al., 2009).

Uji organoleptik dilakukan oleh 30 panelis tidak terlatih dengan mengukur tingkat kesukaan panelis dengan skala numerik 1-7 (Setyaningsih et al., 2010).
Data organoleptik dianalisis menggunakan chi-square pada taraf uji $\alpha(0,05)$. Pemilihan perlakuan terbaik menggunakan metode indeks efektivitas dengan prosedur pembobotan (De Garmo et al., 1984).

\section{HASIL DAN PEMBAHASAN}

\section{Karakteristik Fisik Permen Jeli Kopi Robusta}

Tekstur Permen Jeli Kopi Robusta

Berdasarkan hasil ANOVA pada taraf uji 5\%, konsentrasi sukrosa dan perbandingan gelatin karagenan berpengaruh nyata begitupun dengan interaksi keduanya terhadap tekstur (hardness) permen jeli kopi yang dihasilkan. Nilai tekstur (hardness) permen jeli kopi robusta ditunjukkan pada Gambar 1.

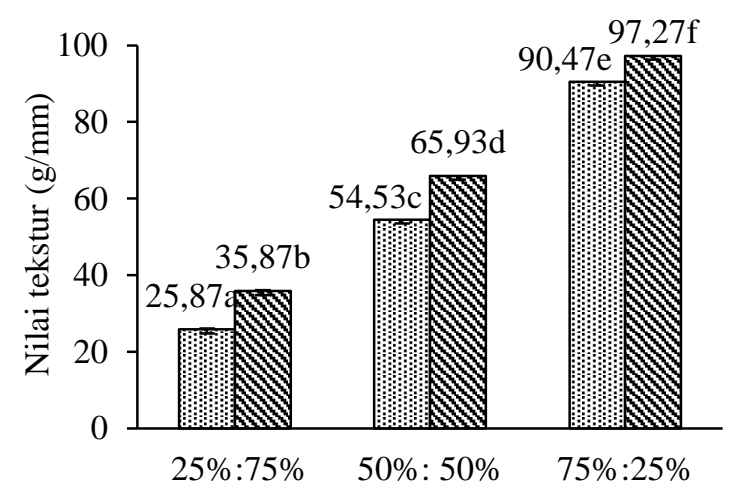

Konsentrasi gelatin:karagenan

Gambar 1. Nilai tekstur permen jeli kopi robusta dengan penambahan sukrosa $40 \%$ (i!tia) dan $60 \%$ (N)

Nilai tekstur (hardness) yang tertinggi terdapat pada konsentrasi gelatin:karagenan (75\%:25\%) dengan konsentrasi sukrosa $60 \%$ sebesar 97,27 $\mathrm{g} / \mathrm{mm}$, sedangkan nilai tekstur (hardness) terendah terdapat pada konsentrasi gelatin:karagenan $(25 \%: 75 \%)$ dan sukrosa $40 \%$ sebesar $25,87 \mathrm{~g} / \mathrm{mm}$. Hal ini menunjukkan bahwa semakin tinggi konsentrasi gelatin dan sukrosa maka semakin tinggi nilai tekstur yang dihasilkan seiring dengan semakin rendah konsentrasi 
karagenan yang ditambahkan. Penambahan sukrosa berpengaruh terhadap tekstur permen jeli.

Menurut Murtiningsih (2018), semakin tinggi penambahan konsentrasi gelatin dan sukrosa menyebabkan tekstur permen jeli yang dihasilkan lebih kokoh atau keras, karena selama proses pemanasan ikatan hidrogen antar molekul dalam gelatin, molekul tersebut akan terurai dan terbentuk ikatan silang antar molekul. Sukrosa akan membantu menghubungkan ikatan tersebut untuk memerangkap air sehingga gel yang dihasilkan lebih kuat. Kombinasi gelatin dan karagenan akan menghasilkan tekstur yang khas. Menurut Fardiaz (2011), pembentukan gel oleh karagenan terjadi akibat penggabungan atau ikatan silang antar rantai-rantai polimer sehingga terbentuk jala 3 dimensi bersambungan. Jaringan akan menyerap air di dalamnya dan membentuk struktur kuat dan kenyal.

\section{Warna (Kecerahan/Lightness) Permen Jeli Kopi Robusta}

Nilai warna ditunjukkan pada tingkat kecerahan L (lightness) pada permen jeli kopi robusta. Berdasarkan hasil ANOVA pada taraf uji 5\% menunjukkan bahwa konsentrasi sukrosa dan perbandingan gelatin karagenan berpengaruh nyata begitupun dengan interaksi keduanya terhadap warna permen jeli kopi yang dihasilkan. Nilai kecerahan permen jeli kopi robusta tersaji pada Gambar 2.

Nilai kecerahan tertinggi terdapat pada permen jeli kopi dengan penambahan gelatin:karagenan $(25 \%: 75 \%)$ dan sukrosa $40 \%$ sebesar 49,95; sedangkan nilai terendah terdapat pada permen jeli kopi dengan penambahan gelatin:karagenan (75\%:25\%), dan sukrosa 60\% sebesar 39,92. Permen jeli kopi dengan konsentrasi gelatin dan sukrosa paling rendah menghasilkan nilai kecerahan yang paling tinggi, sebaliknya permen jeli kopi dengan konsentrasi gelatin dan sukrosa paling tinggi menghasilkan nilai kecerahan yang paling rendah. Hal ini menunjukkan bahwa semakin tinggi konsentrasi gelatin dan sukrosa yang digunakan maka kecerahan permen jeli yang dihasilkan akan semakin rendah, sehingga permen jeli yang dihasilkan akan semakin gelap.

Penambahan gelatin dan sukrosa pada permen jeli kopi menyebabkan terjadinya reaksi maillard. Menurut Kusnandar (2010), reaksi maillard terbentuk karena adanya asam-asam amino yang terkandung dalam protein dapat bereaksi dengan gugus keton dan aldehid pada gula pereduksi menghasilkan senyawa melanoidin yang berwarna coklat. Oleh karena itu, semakin banyak gelatin dan sukrosa yang ditambahkan maka reaksi maillard akan semakin besar sehingga warna produk semakin gelap.

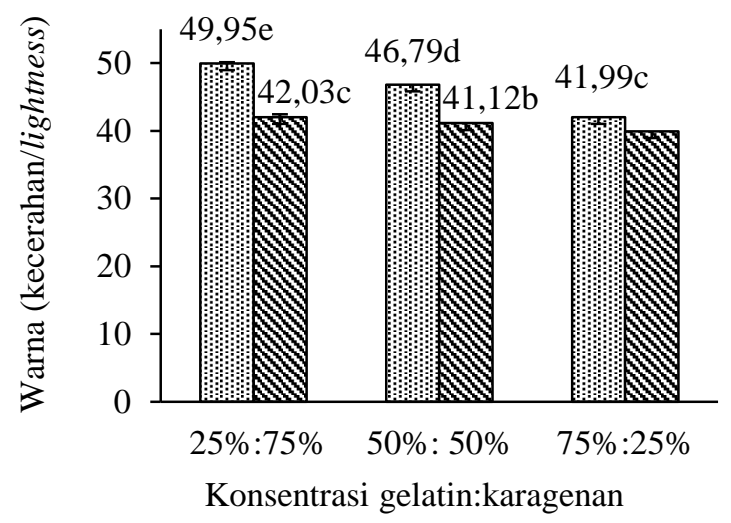

Gambar 2. Nilai warna (kecerahan/lightness) permen jeli kopi robusta dengan penambahan sukrosa $40 \%$ (an dan $60 \%$ (N)

\section{Kadar Air Permen Jeli Kopi Robusta}

Kadar air berperan penting dalam menentukan tekstur, cita rasa, dan gizi bahan pangan. Berdasarkan hasil ANOVA pada taraf uji 5\% menunjukkan bahwa konsentrasi sukrosa dan perbandingan gelatin karagenan berpengaruh nyata begitupun dengan interaksi keduanya terhadap kadar air permen jeli kopi yang dihasilkan. Nilai kadar air permen jeli kopi tersaji pada Gambar 3. 


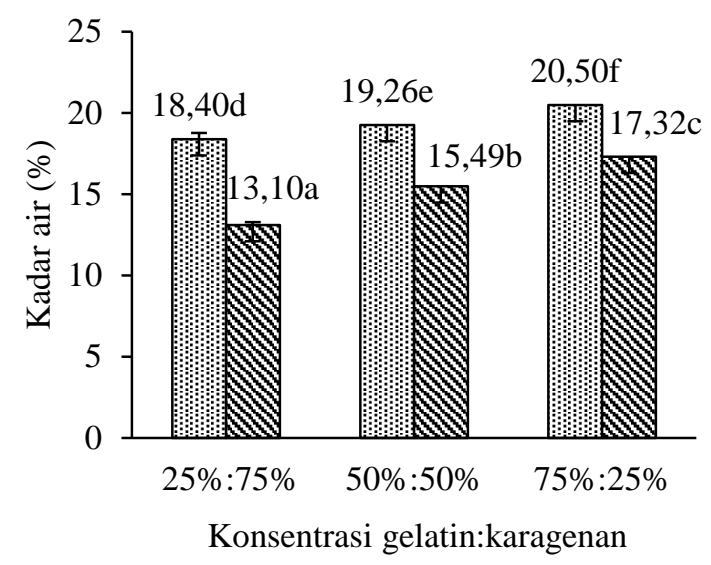

Gambar 3. Nilai kadar air permen jeli kopi robusta dengan penambahan sukrosa $40 \%$ (:iti dan $60 \%$ (N)

Kadar air tertinggi terdapat pada permen jeli kopi dengan penambahan konsentrasi sukrosa $40 \%$ dan gelatin:karagenan $\quad(75 \%: 25 \%)$ yaitu 20,50\%; sedangkan kadar air terendah pada konsentrasi sukrosa $60 \%$ dan gelatin:karagenan $\quad(25 \%: 75 \%)$ sebesar $13,10 \%$. Hal ini menunjukkan bahwa semakin tinggi penambahan sukrosa dan karagenan maka semakin rendah kadar air yang dihasilkan seiring dengan semakin tinggi penambahan gelatin. Menurut Engka (2016), gula bersifat mampu mengikat air pada suatu bahan sehingga dapat mengurangi kadar air dalam suatu produk.

Kombinasi penambahan gelatin dan karagenan akan berpengaruh terhadap kadar air permen jeli kopi. Hal ini dikarenakan sifat gelatin dan karagenan yang mampu mengikat air sehingga molekul air terperangkap dalam struktur gel yang terbentuk. Menurut Hambali et al. (2004), gelatin merupakan system disperse koloid yang dapat dengan mudah menyerap air dalam jumlah yang besar (bersifat hidrofilik). Gelatin akan membantu pengikatan air dalam jumlah besar dan membentuk jaringan yang akan menghambat pergerakan air. Karagenan bersifat mengikat air karena memiliki gugus sulfat bermuatan negatif sepanjang rantai polimernya. Karagenan bersifat mengikat air karena memiliki gugus sulfat bermuatan negatif sepanjang rantai polimernya. Menurut Harun (2013), semakin tinggi konsentrasi karagenan yang ditambahkan maka jumlah air bebas yang ada di dalam bahan berkurang sehingga menyebabkan pembentukan struktur gel menjadi kuat.

\section{Kadar Abu Permen Jeli Kopi Robusta}

Kadar abu berkaitan dengan kandungan mineral dalam bahan pangan. Unsur mineral dikenal sebagai zat anorganik atau abu (Winarno, 1997). Berdasarkan hasil ANOVA pada taraf uji $5 \%$ menunjukkan bahwa konsentrasi sukrosa dan perbandingan gelatin karagenan berpengaruh nyata begitupun dengan interaksi keduanya terhadap kadar abu permen jeli kopi yang dihasilkan. Nilai kadar abu permen jeli kopi robusta ditunjukkan pada Gambar 4.

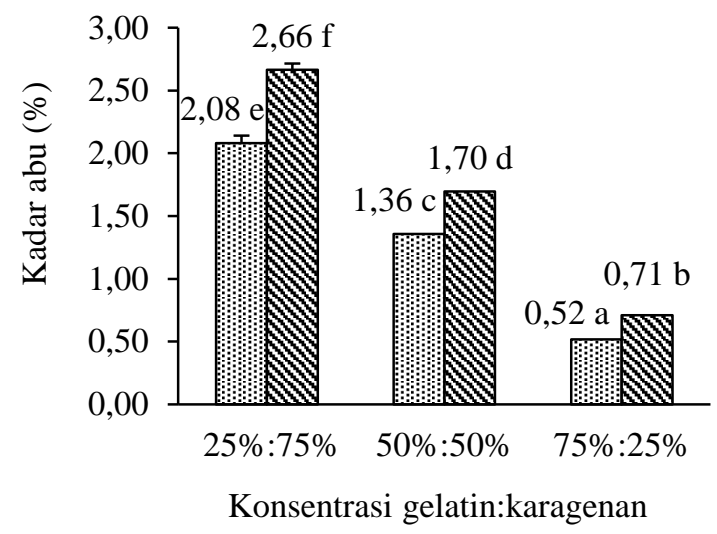

Gambar 4. Nilai kadar abu permen jeli kopi robusta dengan penambahan sukrosa $40 \%$ (ition dan $60 \%$ (N)

Kadar abu tertinggi yaitu 2,66\% terdapat pada permen jeli kopi dengan penambahan sukrosa $60 \%$ dan gelatin:karagenan (25\%:75\%), sedangkan nilai terendah yaitu $0,52 \%$ terdapat pada permen jeli kopi dengan penambahan sukrosa $40 \%$ dan gelatin:karagenan (75\%:25\%). Hal ini menunjukkan bahwa semakin tinggi penambahan sukrosa dan karagenan maka semakin tinggi kadar abu 
seiring dengan semakin rendah penambahan gelatin.

Peningkatan kadar abu menunjukkan banyaknya kandungan mineral dalam bahan pangan tersebut. Sukrosa mengandung mineral yaitu fosfor dan kalsium sehingga penambahan sukrosa menyebabkan semakin tinggi kadar abu dalam permen jeli kopi. Kombinasi penambahan gelatin dan karagenan akan berpengaruh terhadap kadar abu permen jeli kopi. Menurut Hastuti \& Ninik (2014), gelatin mengandung mineral $2-4 \%$. Penambahan karagenan dapat meningkatkan kadar abu permen jeli kopi karena karagenan banyak mengandung mineral seperti $\mathrm{Na}, \mathrm{Ca}, \mathrm{K}, \mathrm{Cl}, \mathrm{Mg}, \mathrm{Fe}, \mathrm{S}$, dan Iod yang tinggi sebagai sumber abu (Sukri, 2006).

\section{Aktivitas Antioksidan Permen Jeli Kopi Robusta}

Pengukuran aktivitas antioksidan pada penelitian ini menggunakan metode DPPH. Pada prinsipnya, metode ini didasarkan pada perubahan warna senyawa DPPH karena bereaksi dengan antioksidan. Berdasarkan hasil ANOVA pada taraf uji 5\% menunjukkan tidak berpengaruh nyata antara variasi konsentrasi sukrosa dan perbandingan gelatin karagenan begitupun dengan interaksi keduanya terhadap aktivitas antioksidan permen jeli kopi yang dihasilkan.

Pada permen jeli kopi robusta, aktivitas antioksidan tertinggi diperoleh pada perlakuan konsentrasi sukrosa $40 \%$ dan perbandingan gelatin karagenan (50\%:50\%) sebesar 26,63\%, sedangkan nilai aktivitas antioksidan terendah diperoleh pada perlakuan konsentrasi sukrosa $60 \%$ dan perbandingan gelatin karagenan (50\%:50\%) sebesar 26,30\% (Gambar 5). Konsentrasi ekstrak kopi yang digunakan pada penelitian ini untuk semua perlakuan jumlahnya sama yaitu sebesar $20 \mathrm{~mL}$, sehingga nilai aktivitas antioksidan yang dihasilkan relatif sama dan tidak ada perbedaan yang signifikan.
Menurut Pokorna et al. (2015), aktivitas antioksidan dalam kopi robusta lebih tinggi $(63,2 \%)$ dibandingkan dengan kopi arabika $(60,4 \%)$.

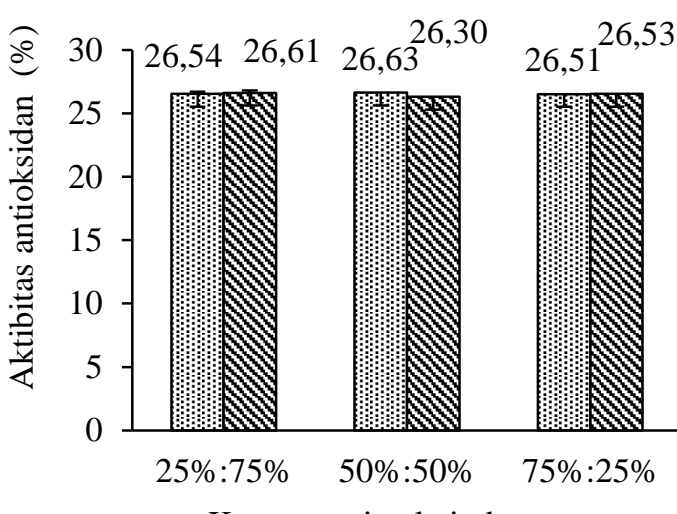

Gambar 5. Nilai aktivitas antioksidan permen jeli kopi robusta dengan penambahan sukrosa $40 \%$ (ifing

\section{Total Polifenol Permen Jeli Kopi Robusta}

Analisis total polifenol dilakukan dengan metode follin ciocalteau yang didasarkan pada kemampuan sampel dalam mereduksi reagen senyawa kompleks molubdenum-tungstat yang berwarna biru (Fauzi et al., 2019). Berdasarkan hasil anova pada taraf uji 5\% menunjukkan tidak berpengaruh nyata antara variasi konsentrasi sukrosa dan perbandingan gelatin karagenan begitupun dengan interaksi keduanya terhadap total polifenol permen jeli kopi robusta yang dihasilkan (Gambar 6).

Pada permen jeli kopi robusta, total polifenol tertinggi diperoleh pada perlakuan konsentrasi sukrosa 40\%, 60\%, dan perbandingan gelatin karagenan (50\%:50\%) sebesar 0,46 $\mathrm{mg}$ GAE/mL, sedangkan total polifenol terendah diperoleh pada perlakuan konsentrasi sukrosa $40 \%$ dan perbandingan gelatin karagenan (25\%:75\%) dan (75\%:25\%) sebesar $0,42 \mathrm{mg}$ GAE/mL. Nilai total polifenol pada permen jeli kopi berbanding lurus dengan nilai aktivitas antioksidan. Konsentrasi sukrosa dan perbandingan gelatin-karagenan tidak berpengaruh nyata 
terhadap total polifenol permen jeli kopi. Hal ini dikarenakan jumlah ekstrak kopi yang ditambahkan sama. Kopi robusta mengandung polifenol tinggi. Menurut Setyani et al. (2017), golongan polifenol yang terdapat dalam kopi robusta yaitu asam klorogenat, kafein, dan ferullic acid. Golongan polifenol ini menunjukkan adanya senyawa antioksidan di dalam permen jeli kopi. Jumlah asam klorogenat mencapai $90 \%$ dari total polifenol dalam kopi.

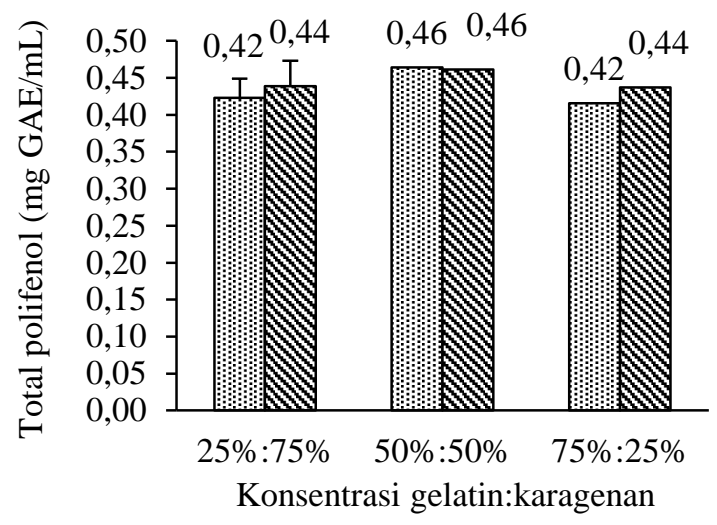

Gambar 6. Nilai total polifenol permen jeli kopi robusta dengan penambahan sukrosa $40 \%$ (ifis) dan $60 \%$ (N)

\section{Uji Organoleptik Permen Jeli Kopi Robusta \\ Kesukaan Warna Permen Jeli Kopi Robusta}

Warna merupakan salah satu parameter organoleptik yang penting terutama dalam hal daya tarik, tanda pengenal, dan atribut mutu. Warna merupakan parameter pertama yang menentukan tingkat penerimaan konsumen terhadap suatu produk. Berdasarkan hasil uji chi-square pada taraf uji $\alpha(0,05)$ diketahui bahwa variasi perlakuan konsentrasi sukrosa dan perbandingan gelatin karagenan berpengaruh nyata terhadap kesukaan warna permen jeli kopi. Nilai kesukaan warna permen jeli kopi robusta tersaji pada Gambar 7.

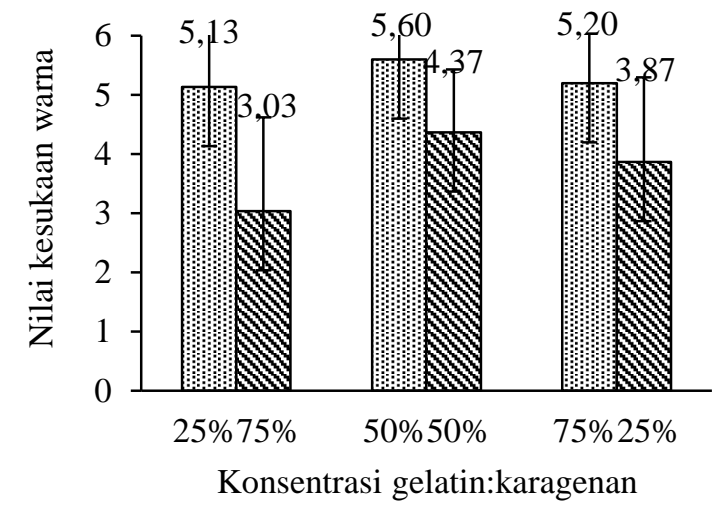

Gambar 7. Nilai kesukaan warna permen jeli kopi robusta dengan penambahan sukrosa $40 \%$ (ition

Tingkat kesukaan panelis yang paling tinggi terhadap warna permen jeli kopi robusta pada konsentrasi sukrosa $40 \%$ dan gelatin:karagenan 50\%:50\% dengan nilai kesukaan 5,60 (suka), sedangkan untuk tingkat kesukaan warna terendah terdapat pada konsentrasi sukrosa $60 \%$ dan gelatin:karagenan (25\%:75\%) dengan nilai kesukaan 3,03 (agak tidak suka). Hal tersebut menunjukkan bahwa semakin tinggi penambahan sukrosa dan gelatin maka semakin tinggi tingkat kesukaan panelis pada warna permen jeli kopi. Penambahan sukrosa dan gelatin dapat menghasilkan warna coklat kehitaman pada permen jeli kopi robusta karena adanya reaksi maillard. Gelatin yang digunakan dalam penelitian ini berwarna kuning kecoklatan, sehingga dapat mempengaruhi produk akhir permen jeli kopi. Hal ini menyebabkan warna produk yang semakin gelap seiring meningkatnya konsentrasi gelatin yang digunakan.

\section{Kesukaan Aroma Permen Jeli Kopi Robusta}

Aroma merupakan salah satu sifat sensoris yang dapat menggambarkan rasa dari suatu produk meskipun produk tersebut belum dikonsumsi oleh konsumen. Selain itu aroma juga dapat menentukan bahan-bahan yang digunakan untuk membuat produk tersebut. Berdasarkan hasil uji chi-square pada taraf uji $\alpha(0,05)$ 
diketahui bahwa variasi perlakuan konsentrasi sukrosa dan perbandingan gelatin karagenan berpengaruh nyata terhadap kesukaan aroma permen jeli kopi. Nilai kesukaan aroma permen jeli kopi robusta ditunjukkan pada Gambar 8.

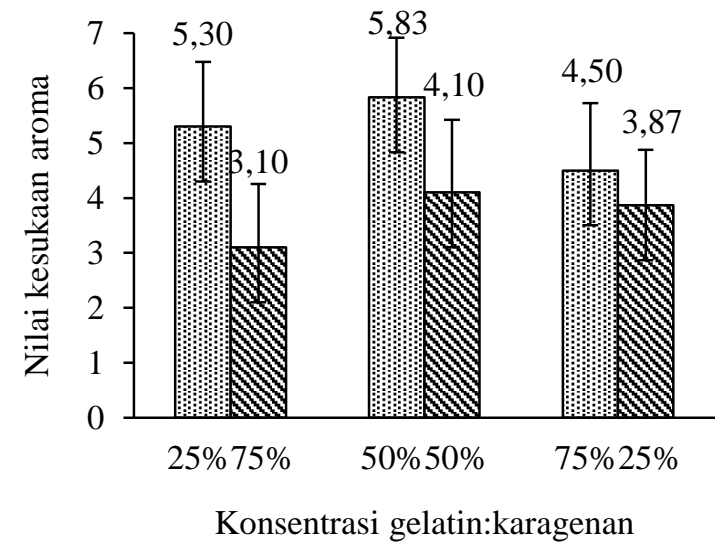

Gambar 8. Nilai kesukaan aroma permen jeli kopi robusta dengan penambahan sukrosa $40 \%$ (

Tingkat kesukaan panelis yang paling tinggi terhadap aroma permen jeli kopi robusta pada konsentrasi sukrosa $40 \%$, gelatin:karagenan (50\%:50\%) sebesar 5,83 (suka). Aroma yang dihasilkan dari permen jeli adalah aroma khas dari kopi. Ridwansyah (2003) menyatakan bahwa aroma khas kopi dihasilkan oleh terbentuknya senyawa volatil, karamelisasi karbohidrat, dan terbentuknya gas $\mathrm{CO}_{2}$ sebagai hasil oksidasi.

Selain penambahan kopi, penambahan sukrosa, gelatin, dan karagenan juga dapat berpengaruh terhadap aroma permen jeli. Panelis kurang menyukai permen jeli kopi dengan penambahan karagenan yang tinggi. Menurut Eveline (2009), penambahan karagenan dalam produk pangan dapat menimbulkan aroma amis pada permen jeli sehingga semakin tinggi penambahan karagenan menyebabkan tingkat kesukaan aroma permen jeli menurun.

\section{Kesukaan Tekstur Permen Jeli Kopi Robusta}

Tekstur merupakan karakteristik penting yang dapat mempengaruhi kesukaan panelis terhadap suatu produk. Berdasarkan hasil uji chi-square pada taraf uji $\alpha \quad(0,05)$ diketahui bahwa variasi perlakuan konsentrasi sukrosa dan perbandingan gelatin karagenan berpengaruh nyata terhadap kesukaan tekstur permen jeli kopi. Nilai kesukaan tekstur permen jeli kopi robusta tersaji pada Gambar 9.

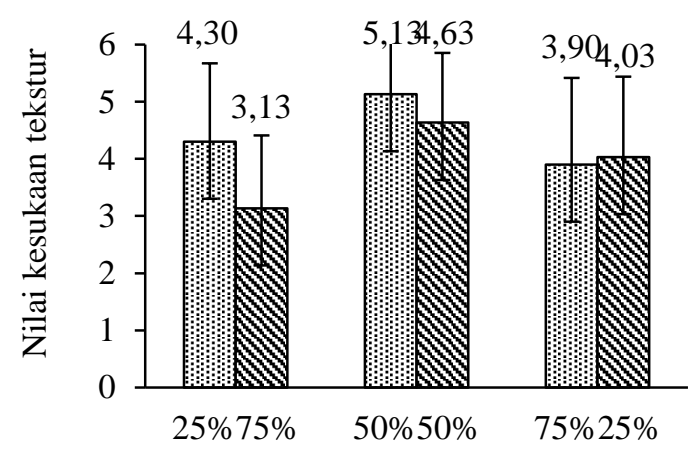

Konsentrasi gelatin:karagenan

Gambar 9. Nilai kesukaan tekstur permen jeli kopi robusta dengan penambahan sukrosa $40 \%$ (t: dan $60 \%$ (N)

Berdasarkan Gambar 9, panelis lebih menyukai tekstur permen jeli kopi dengan konsentrasi sukrosa $40 \%$ dan gelatin:karagenan (50\%:50\%) karena teksturnya lebih kokoh dan elastis. Permen jeli kopi dengan konsentrasi sukrosa $60 \%$, dan gelatin:karagenan (25\%:75\%) kurang disukai karena teksturnya terlalu lunak dan mudah hancur. Hal ini menunjukkan bahwa penambahan sukrosa, gelatin, dan karagenan dapat berpengaruh terhadap kesukaan tekstur permen jeli kopi. Semakin tinggi penambahan sukrosa dan gelatin maka semakin tinggi tingkat kesukaan panelis pada tekstur permen jeli kopi. Penambahan sukrosa akan memperkuat pembentukan gel gelatin sehingga tekstur yang dihasilkan elastis dan tidak terlalu remah. Menurut Rahmi et al. (2012), semakin tinggi penambahan gelatin 
menyebabkan gel yang terbentuk akan kaku atau lebih kokoh, sedangkan semakin rendah penambahan gelatin maka tekstur permen jeli yang terbentuk lebih lunak.

\section{Kesukaan Rasa Permen Jeli Kopi Robusta}

Rasa merupakan salah satu parameter yang penting terhadap suatu makanan karena jika suatu produk memiliki rasa yang tidak disukai akan cenderung kurang diminati di pasaran. Berdasarkan hasil uji chi-square pada taraf uji $\alpha(0,05)$ diketahui bahwa variasi perlakuan konsentrasi sukrosa dan perbandingan gelatin karagenan berpengaruh nyata terhadap kesukaan rasa permen jeli kopi. Nilai kesukaan rasa permen jeli kopi tersaji pada

\section{Gambar 10.}

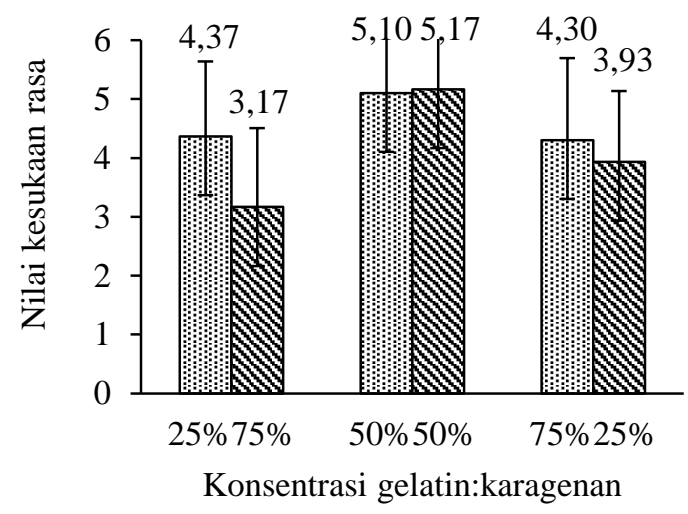

Gambar 10. Nilai kesukaan rasa permen jeli kopi robusta dengan penambahan sukrosa $40 \%$ (tid) dan $60 \%$

Nilai kesukaan paling tinggi terhadap rasa permen jeli kopi yaitu 5,17 (suka) pada konsentrasi sukrosa $60 \%$, gelatin:karagenan (50\%:50\%), sedangkan nilai terendah yaitu pada permen jeli dengan konsentrasi sukrosa $60 \%$, gelatin:karagenan (25\%:75\%) sebesar 3,17 (agak tidak suka). Panelis lebih menyukai permen jeli kopi dengan penambahan sukrosa yang tinggi karena rasa manisnya yang kuat serta dapat menutupi rasa pahit dari kopi. Menurut Hasniarti (2012), penambahan gula berfungsi sebagai bahan pemanis, penambah cita rasa, pengawet, dan dapat memperbaiki penampilan produk.

Panelis kurang menyukai permen jeli kopi dengan penambahan karagenan yang banyak. Semakin tinggi penambahan karagenan menyebabkan rasa khas kopi dalam permen jeli tertutupi. Hal ini sesuai dengan pendapat Piccone et al. (2011), bahwa penambahan senyawa hidrokoloid dalam produk pangan dapat mengurasi rasa dan aroma asli pada produk tersebut.

\section{Kesukaan Keseluruhan Permen Jeli Kopi}

Kesukaan keseluruhan merupakan penilaian dari panelis terhadap penampilan secara keseluruhan baik parameter warna, aroma, rasa, dan tekstur. Berdasarkan hasil uji chi-square pada taraf uji $\alpha(0,05)$ diketahui bahwa variasi perlakuan konsentrasi sukrosa dan perbandingan gelatin karagenan berpengaruh nyata terhadap kesukaan keseluruhan permen jeli kopi. Nilai kesukaan keseluruhan permen jeli kopi robusta ditunjukkan pada Gambar 11.

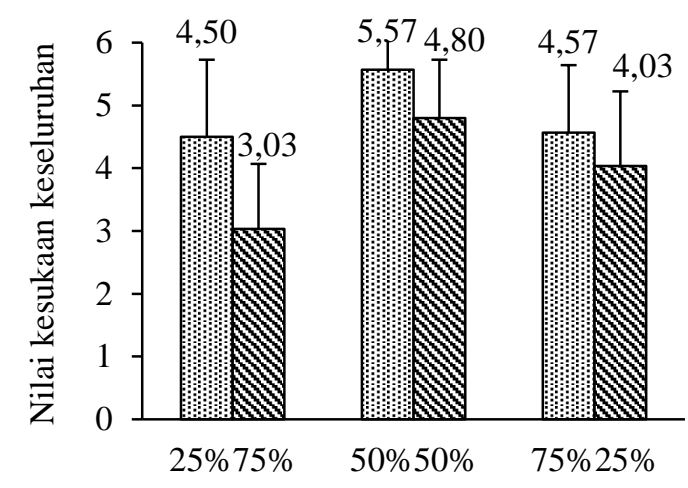

Konsentrasi gelatin:karagenan

Gambar 11. Nilai kesukaan keseluruhan permen jeli kopi robusta dengan penambahan sukrosa $40 \%$ (i: dan $60 \%$ (N)

Nilai kesukaan panelis paling tinggi terhadap keseluruhan permen jeli kopi robusta yaitu 5,57 pada permen dengan konsentrasi sukrosa 40\%, gelatin:karagenan (50\%:50\%), sedangkan nilai terendah yaitu 3,03 pada permen dengan konsentrasi sukrosa $60 \%$, 
gelatin:karagenan $\quad(25 \%: 75 \%)$. Data tersebut menunjukkan bahwa semakin tinggi penambahan sukrosa dan gelatin dapat meningkatkan penilaian kesukaan panelis terhadap keseluruhan permen jeli kopi. Hal ini terjadi karena semakin banyak penambahan sukrosa, dan gelatin akan berpengaruh terhadap warna, rasa, aroma, dan tekstur permen jeli kopi yang dihasilkan.

\section{Uji Efektivitas Permen Jeli Kopi Robusta}

Nilai efektivitas dilakukan untuk menentukan perlakuan terbaik pada permen jeli kopi. Berdasarkan uji efektivitas menunjukkan bahwa nilai hasil uji efektivitas permen jeli kopi dengan variasi konsentrasi sukrosa dan perbandingan konsentrasi gelatin karagenan berkisar antara 0,20-0,80. Nilai efektivitas permen jeli kopi robusta tersaji pada Tabel 1.

Tabel 1. Nilai efektivitas permen jeli kopi robusta

\begin{tabular}{cc}
\hline Perlakuan & Nilai efektivitas \\
\hline P1B1 & 0,53 \\
P1B2 & 0,80 \\
P1B3 & 0,45 \\
P2B1 & 0,20 \\
P2B2 & 0,55 \\
P2B3 & 0,39 \\
\hline
\end{tabular}

Keterangan: P1 = konsentrasi sukrosa $40 \%$

$\mathrm{P} 2=$ konsentrasi sukrosa $60 \%$

$\mathrm{B} 1=25 \%$ gelatin dan $75 \%$ karagenan

$\mathrm{B} 2=50 \%$ gelatin dan $50 \%$ karagenan $\mathrm{B} 3=75 \%$ gelatin dan $25 \%$ karagenan

Perlakuan terbaik pada penelitian ini adalah sampel dengan kode P1B2 (Tabel 1). Sampel tersebut merupakan permen jeli kopi robusta yang memiliki komposisi sukrosa $40 \%$ dan perbandingan gelatin:karagenan 50\%:50\% dengan nilai efektivitas 0,80 . Perlakuan permen kopi robusta tersebut memiliki tekstur (hardness) sebesar 54,53 g/mm, kadar air yang tidak melebihi batas maksimum $20 \%$ dari SNI 3547.2-2008 yaitu 19,26\% dan kadar abu yang tidak melebihi batas maksimum 3,0\% dari SNI 2008 yaitu 1,36\%. Aktivitas antioksidan dan total polifenol yang cukup tinggi berturut-turut yaitu $26,63 \%$ dan $0,46 \mathrm{mg} \mathrm{GAE} / \mathrm{mL}$. Berdasarkan tingkat kesukaan secara keseluruhan, panelis menyukai permen jeli kopi pada perlakuan sukrosa $40 \%$ dan perbandingan gelatin:karagenan 50\%:50\% yaitu pada skor 5,57.

\section{KESIMPULAN}

Penambahan sukrosa dan perbandingan gelatin karagenan berpengaruh nyata $(\alpha=5 \%)$ terhadap tekstur, warna, kadar air, dan kadar abu, serta uji organoleptik meliputi warna, aroma, tekstur, rasa, dan keseluruhan permen jeli kopi robusta, dan tidak berpengaruh nyata terhadap aktivitas antioksidan dan total polifenol. Berdasarkan hasil perhitungan indeks efektivitas, perlakuan terbaik diambil dari nilai tertingi, dari konsentrasi penambahan sukrosa $40 \%$ dan perbandingan gelatin:karagenan 50\%:50\% dengan tekstur sebesar $54,53 \mathrm{~g} / \mathrm{mm}$; warna/lightness sebesar 46,79; kadar air sebesar 19,26\%; kadar abu sebesar 1,36\%; aktivitas antioksidan sebesar 26,63\%; dan total polifenol sebesar 0,46 $\mathrm{mg} \mathrm{GAE} / \mathrm{mL}$, nilai kesukaan warna 5,60 (suka), nilai kesukaan aroma 5,83 (suka), nilai kesukaan tekstur 5,13 (suka), nilai kesukaan rasa 5,10 (suka), dan nilai kesukaan keseluruhan 5,57 (suka).

\section{UCAPAN TERIMA KASIH}

Ucapan terima kasih penulis kepada Universitas Jember melalui Hibah Internal Universitas Jember yang telah mendanai penelitian ini dan kepada semua pihak yang telah membantu penelitian ini.

\section{DAFTAR PUSTAKA}

AOAC. (2005). Official Methods of Analysis. Association of Official Analytical Chemists. Washington D.C: Benyamin Franklin Station. 
Badan Standarisasi Nasional. (2008). SNI 3547.2-2008. Kembang Gula-Bagian 2: Lunak. Jakarta: Badan Standarisasi Nasional.

Basuki, E.K., Mulyani, T., \& Hidayat, L. (2014). Pembuatan permen jelly nanas dengan penambahan karagenan dan gelatin. Jurnal Rekapangan, 8(1), 39-49.

Campo, V.L., Kawano, D.F., da Silva, J.D.B., \& Carvalho, I. (2009). Carragenans: Biological properties, chemical modifications, and structural analysis. A Review. Carbo. Poly., 77(2), 167-180.

De Garmo, E.P., Sullivan, W.G., \& Canada, J.R. (1982). Engineering Economy. New York: McMillan Pub. Co.

Direktorat Jenderal Perkebunan. (2019). Statistik Perkebunan Indonesia Komoditas Kopi 2018-2020. Jakarta: Sekretariat Direktorat Jenderal Perkebunan, Direktorat Jenderal Perkebunan, Kementerian Pertanian.

Duconseille, A., Astruc, T., Quintana, N., Meersman, F., \& Sante-Lhoutellier, V.E. (2015). Gelatin structure and composition linked to hard capsule dissolution: A review. Journal Food Hydrocolloids, 43, 360-376.

Engka. (2016). Pengaruh konsentrasi sukrosa dan sirup glukosa terhadap sifat kimia dan sensoris permen keras belimbing wuluh (Averrhoa bilimbi L.). Jurnal Teknologi Pertanian, 7(3), 49-58.

Eveline, Santoso, J., \& Widjaya, I. (2009). Pengaruh konsentrasi dan rasio gelatin dari kulit ikan patin dan kappa karagenan dari Eucheuma cottonii pada pembuatan jeli. Jurnal Ilmu dan Teknologi Pangan, 7(2), 55-75.

Fardiaz, S. (2011). Hidrokoloid. Laboratorium Mikrobiologi Pangan PAU. Bogor: IPB.

Fauzi, M., Novijanto, N., \& Rarasati, D.P. (2019). Karakteristik organoleptik dan fisikokimia kopi jahe celup pada variasi tingkat penyangraian dan konsentrasi bubuk jahe. Jurnal Agroteknologi, 13(1), $1-9$.
Hambali, E., Suryani, A., \& Widianingsih, N. (2004). Membuat Aneka Olahan Mangga. Jakarta: Penebar Swadaya.

Harun. (2013). Karakteristik fisika kimia karagenan rumput laut jenis Kappaphycus alvarezii pada umur panen yang berbeda di perairan desa Tihengo, Kab Gorontalo Utara. Jurnal Media Teknologi Hasil Perikanan, 1, 5-6.

Hasniarti. (2012). "Studi Pembuatan Permen Buah Dengen (Dillenia serrate Thumb.)". Skripsi. Program Studi Ilmu dan Teknologi Pangan, Jurusan Teknologi Pertanian. Universitas Hasanuddin, Makassar.

Hastuti, A.M., \& Ninik, R. (2014). Pengaruh penambahan kayu manis terhadap aktivitas antioksidan dan kadar gula total minuman fungsional secang dan daun stevia sebagai alternatif minuman bagi penderita diabetes melitus tipe 2. Journal of Nutrition College, 3(3), 362-369.

Kusnandar, F. (2010). "Memahami Proses Termal dalam Pengawetan Pangan". Skripsi. Departemen Ilmu Teknologi Pangan. Institut Pertanian Bogor, Bogor.

Liu, L., Sun, Y., Laura, T., Liang, X., Ye, H., \& Zeng, X. (2009). Determination of polyphenolic content and antioxidant activity of kudingcha made from Ilex Kudingcha C.J. Tseng. Journal of Food Chemistry, 112, 35-41.

Marsigit, W., Tutuarima, T., \& Hutapea, R. (2018). Pengaruh penambahan gula dan karagenan terhadap karakteristik fisik, kimia, dan organoleptik soft candy jeruk kalamansi (Citrofortunella microcarpa). Jurnal Agroindustri, 8(2), 113-123.

Murtiningsih. (2018). Pembuatan permen jeli kulit buah naga merah kajian konsentrasi sukrosa dan gelatin. Reka Pangan, 12(1), 67-77.

Noer, S., Pratiwi, R.D., \& Gresinta, E. (2018). Penetapan kadar senyawa fitokimia (tanin, saponin dan flavonoid) sebagai kuersetin pada ekstrak daun inggu (Ruta angustifolia L.). Jurnal Eksakta, 18(1), 19-29. 
Piccone, P., Rastelli, S.L., \& Pittia, P. (2011). Aroma Release and Sensory Perception of Fruit Candies Model Systems. Procedia Food Science, 1, 1509-1515.

Pokorna, J., Venskutonis, P.R., Kraujalyte, V., Kraujalis, P., Dvorak, P., Tremlova, B., Kopriva, V., \& Ostadalova. (2015). Comparison of different methods of antioxidant activity evaluation of green and roast $C$. arabika and $C$. robusta coffee beans. Acta Alimentaria, 44(3), 454-460.

Prihardhani, D.I., \& Yunianta, Y. (2016). Ekstraksi gelatin kulit ikan lencam (Lentrinus sp.) dan aplikasinya untuk produk permen jeli. Jurnal Pangan dan Agroindustri, 4(1), 356-366.

Rahmi, A.L., Tafzi, F., \& Anggraini, S. (2012). Pengaruh penambahan gelatin terhadap pembuatan permen jelly dari bunga rosella (Hibiscus sabdariffa Linn). Jurnal Penelitian Universitas Jambi Seri Sains, 14(1), 37-44.

Ridwansyah. (2003). Pengolahan Kopi. Medan: Universitas Sumatra Utara Press.

Riedel, R., Bohme, B., \& Rohm, H. (2015). Development of formulations for reduced sugar and sugar free agar based fruit jellies. International Journal of Food Science and Technology, 50(6), 1338-1344.

Roy, M.K., Juneja, L.R., Isobe, S., \& Tsuhida, T. (2009). Steam processed broccoli (Brassica oleracea) has higher antioxidant activity in chemical and cellular assay systems. Food Chemistry, 114, 263-269.

Setyani, S., Subeki, \& Grace, H.A. (2017). Karakteristik sensori, kandungan kafein, dan asam klorogenat kopi bubuk robusta (Coffea canephora L.) di Tanggamus, Lampung. Seminar Nasional Perhimpunan Ahli Teknologi Pangan Indonesia (PATPI) Bandar Lampung, $10-11$.

Setyaningsih, D., Apriyantono, A., \& Sari, M.P. (2010). Analisis Sensori untuk Industri Pangan dan Agro. IPB Press, Bogor.
Stadler, R.H., Varga, N., Hau, J., Vera, F.A., \& Welti, D.H. (2002). Alkylpyridiniums. 1. Formation in model systems via thermal degradation of trigonelline. Journal of Agricultural and Food Chemistry, 50, 1192-1199.

Sukri, N. (2006). "Karakteristik Alkali Tread Cottoni (ATC) dan Karaginan dari Rumput Laut Euchema cottoni Pada Umur Panen yang Berbeda". Skripsi. Program Studi Teknologi Hasil Perikanan. Fakultas Perikanan dan Ilmu Kelautan, Institut Pertanian Bogor, Bogor.

Wijana, S., Mulyadi, A.F., \& Septivirta, T.D.T. (2014). "Pembuatan Permen Jelly dari Buah Nanas (Ananas comosus L.) Subgrade (Kajian Konsentrasi Karagenan dan Gelatin)”. Skripsi. Universitas Brawijaya, Malang.

Winarno, F.G. (1997). Kimia Pangan dan Gizi. Jakarta: Gramedia Pustaka Utama. 